\title{
Relational value, partnership, eudaimonia: a review
}

DOI:

10.1016/j.cosust.2018.10.022

\section{Document Version}

Accepted author manuscript

Link to publication record in Manchester Research Explorer

\section{Citation for published version (APA):}

Knippenberg, L., De Groot, W. T., Van Den Born, R. J., Knights, P., \& Muraca, B. (2018). Relational value, partnership, eudaimonia: a review. Current Opinion in Environmental Sustainability, 35, 39-45. https://doi.org/10.1016/j.cosust.2018.10.022

\section{Published in:}

Current Opinion in Environmental Sustainability

\section{Citing this paper}

Please note that where the full-text provided on Manchester Research Explorer is the Author Accepted Manuscript or Proof version this may differ from the final Published version. If citing, it is advised that you check and use the publisher's definitive version.

\section{General rights}

Copyright and moral rights for the publications made accessible in the Research Explorer are retained by the authors and/or other copyright owners and it is a condition of accessing publications that users recognise and abide by the legal requirements associated with these rights.

\section{Takedown policy}

If you believe that this document breaches copyright please refer to the University of Manchester's Takedown Procedures [http://man.ac.uk/04Y6Bo] or contact uml.scholarlycommunications@manchester.ac.uk providing relevant details, so we can investigate your claim.

\section{OPEN ACCESS}




\section{Introduction}

Recent papers of Mace [1] and Chan et al. [2] call for a more relational vision of humans and nature, following a line of reasoning that is also visible in the editorial of the present special issue: in addition to any intrinsic value that humans and nature separately may have, could value not also reside in their relationship? Thus, the idea of relational value acts as an antidote against the metaphysics of separation in which relationships between humans and nature can hold nothing of ethical import [3], but also against the vision of transpersonal unification ('oneness') with nature found in Deep Ecology [4]. In the analysis of Cheney [ $\left.5^{*}\right]$, both the quest to conquer nature and the quest to unify with nature come forward as the two prongs of the same (masculine) project. Between these two extremes lies something entirely different, which is the genuine encounter of humans and nature, i.e. relational value.

It is praiseworthy that Chan et al. [2] grounded the concept of relational values broadly in the real-life philosophies of people and communities, but this left the concept itself rather underdeveloped. In the next section, we aim to strengthen the arguments of Chan et al. by further exploring the empirical reality of relational values as well as the conceptual clarity of the relational values idea. Subsequently we will focus on what we think are two productive expressions of the idea of relational values with nature, under the headings of 'partnership with nature' and 'nature-inclusive eudaimonia'.

\section{What are relational values?}

Relational values might be difficult to define within the frame of the Western metaphysical tradition of separation between humans and the world, yet they are very real in real lives. Chan et al. [2] already provide examples and the present section adds more elements from empirical research and religious thought. After that, we venture into a more conceptual exploration of what relational value may be said to be. Throughout the section and the paper as a whole, we define nature as all structures and process around us that we acknowledge as fully or largely spontaneous.

Relational values are real in real lives

In the Europe-wide research project BIOMOT (www.biomotivation.eu), 105 committed actors in nature conservation (in NGOs, government, education and business) were interviewed, inter alia focusing on their life stories and explaining how their commitments grew over the years. In these accounts, allusions to the intrinsic value of nature were virtually nowhere to be found. Rather, all motivations were relational, and more specifically, eudaimonic, that is, focused on the good, meaningful life [6*]. One actor, for instance, described his childhood as "wonderful" and "spent entirely in the forest". After his Masters degree in biology, his desire to make a difference for nature searched for an alternative to "the heavy policy stories of human guilt and human threats and acid rain". Through meditation, reflection and writing, he discovered a new story, along with the new avenue for action: "making use of nature, giving it space, not locking nature up in too much stewardship, involving people in a warm, happy connectedness with wilderness". Jointly with a few others, the actor initiated a rewilding foundation at 
the European level [7]. In another part of the BIOMOT interviews, actors were asked to rank a set of preformulated motivations to work for nature [8]. In that setting, nature's intrinsic value did appear as a motivation for committed action, ranking second. All other motivations in the top- 6 were much more relational ones however, such as no. 1, "curiosity and learning" and no. 3: "living a worthwhile life". Hence the core conclusion of BIOMOT [7]: "Committed action for nature arises in actors that feel connected with nature as part of a life that makes sense and a difference in the world".

A second empirical approach to the discovery of relational value consists of the application of series of statements ('scales') to which people are asked to respond one by one, often in a questionnaire allowing responses between 'fully agree' and 'fully disagree'. Some scales of this type are designed to bring out people's (dis)agreement with relational values [9], in the US often under a notion of 'connectedness with nature' [10] - [14] and sometimes with 'relational values' explicit [15]. Overall, these studies find a substantial acknowledgement of connectedness and relational values in the general public.

A European example of the scales approach is the Humans-and-Nature ( $\mathrm{HaN})$ scale that is grounded in environmental ethics and includes statements expressing four types of relationship with nature: Mastery over nature, Stewardship of nature, Partnership with nature and Participation in nature [16*], partly comparable with Muriadan and Pascual (this volume). (Non-)adherence to the idea of partnership is measured, for instance, with statements such as 'Nature wants to grow, prosper and develop, just like humans do' and 'I would like to have a relationship with nature just like I have with my friends'. Overall, the results are remarkably even across gender, age and European countries (West and East), with Mastery over nature generally rejected, Stewardship of nature massively adhered to, but also Partnership with nature and Participation in nature receiving majority levels of adherence [17] contradicting the received philosophical idea that mastery over nature is the dominant worldview in Western culture. The HaN scale has recently been applied in Vietnam as well [18], with results that reinforce the impression that the adherence to relational values is more universally human than culturally determined; see also [19] on relational values in Colombia, De Vos et al. (this volume) on relational values around protected areas and [20] on the universality of attitudes of children towards nature in very different cultural and class contexts.

A third type of empirical research into relational values focuses on people engaged in material interactions with nature such as farmers, foresters or hunters, seeking to understand the role of relational values with nature in the actions of these people. We know of no systematic review but surely there is a great wealth to explore; see for instance [21] - [25] for research in the West and the great riches of ethnographic literature on non-Western cultures.

\section{Relational values are real in religious thought}

If the acknowledgment of relational values is indeed pervasive and present across cultures, they should be expected to also be found in religious narratives. Authors such as Chan et al. [2], Jackson and Palmer [26], Christ [27], De Groot [28*p. 520] and many others have already explored this point, focusing on Christianity in particular. Without any claim to completeness, we add a few new elements here. 
Can monotheistic religions be said to be relational? In a very basic sense, the answer is not difficult. For most Christian or Muslim faithful, God is not an issue. It's your relationship with Him that counts [29]. For many, this pattern is exemplified by Jesus, and according to the critical analysis of theologian Schillebeeckx [30], the only word in the gospels of which we can be sure it is Jesus' own is Abba, Father, i.e. a purely relational term. Likewise, the Christian sacraments, rather than focusing on God or humans separately, celebrate their relationship.

In the history of Christianity, we find patterns that re-enact Cheney's [5] juxtaposition of unification versus encounter (relationship). In the $13^{\text {th }}$ century, for instance, mysticism contained a current in which the mystic desired to unify with God (to "be raised above the angels", "one with God" in the words of Meister Eckhart) $\left[28^{*}\right]$, but also a (feminine) current that sought to encounter Him in this life, in love and without loss of self-identity; Hadewijch is an example [31].

In Islam, with its rejection of the Trinity idea and strong emphasis on the oneness of God, one would expect a stronger drive towards unification (oneness with God). This One, however, is all-embracing, both the transcendent and the material worlds. Thus in the meditative (Sufi) tradition in Islam, we contemplate the oneness of everything, the unity in all, the kinship of all, as we are kin, cherishing relational values, with our own [32]. In the Qur'an (6:38), God speaks to humankind about nature: "And there is no animal in the earth nor bird that flies with its two wings but that they are communities like yourselves"[33*].

Writing on Daoism, Wong [34] refers to the same pattern of encounter (relationship) versus unification in that religion. In some Daoist sources, the sage is unified with the Whole to an extent that even death is not a real event, only a transformation. Wong argues however that the more authentic Daoist view is relational. The sage rambles, going about in the world without interfering (wu wei), in openness and wonder. "The Daoist self is not a substantial independent existence but a relational one whose boundaries extend into the conventional non-human" (p. 582). And even staying in one place is relational, as said in the DaoDeJing: "In dwelling, be close to the earth" [35]. No wonder, perhaps, that scholars of Chinese religion were early to explore relational value with nature [36].

Language for relational values

Starting out with a technical note, it is good to realize that contrary to many ethical concepts such as virtue, relationships (and places, lives etc.) can be both positive or negative, e.g. including fear, slavery, pollution or destruction. In the foregoing and coming text, we only refer to positively valuable relations, often implicitly and sometimes explicitly ('good relation', 'warm relationship', as well as 'meaningful place', 'worthwhile life' etc.). We must be aware of the time span included in the term 'good' however; good relationships and good lives usually include negative moments, difficult choices, the weathering of harsh conditions and so on; see for instance [25] for an example of the good life in a fishing community in Norway. 
As the carpenter knows about the hammer, things that are real do not require our language, let alone definitions, to be real and to be experienced [37]. Yet even the carpenter sometimes needs to talk about hammers and maybe even define why that other thing over there is not a hammer. For that purpose of communication and reflection, we need to develop language for relational values. The importance of that work lies in the fact that relationships are central to human life. The studies of Baumeister and Leary [38] and Fiske [39], for instance, found that belonging is our most fundamental social need. Only some of us are born to be wild, but all of us are born relata, that is, beings involved in relationships. The biophilia hypothesis [40] adds that nature is part of this picture: humans are born with an innate tendency to affiliate with nature.

As illustrated by the linguistic struggles of relational philosophers such as Heidegger and Whitehead, developing relational language does not come without difficulties, our languages being object-based rather than relational, separation-driven rather than holistic. Already in China more than two thousand years ago, Lau Tzu lamented that "Once a whole is divided, the parts need names. There are already too many names" [35]. This helps understand why a philosopher such as Whitehead puts so much emphasis on the reality of relationships and experience, the "vague totality" that is already real before the names begin [41].

On the way to insight in relational value, we should first of all shed the dichotomy of intrinsic/instrumental value ([42] and Himes and Muraca, this volume). We can then acknowledge that if something does not have intrinsic value, its value does not need to be merely instrumental. This insight is important for a balanced understanding of relational values, because relationships, even though they have a good (they can be harmed, for instance), do not have a good of their own in a moral sense, and therefore do not have intrinsic value. Under the strict intrinsic/instrumental dichotomy, a relationship could then only be seen as serving the good of something else, e.g. the separate friends in a friendship [43]. Beyond the dichotomy, however, a relationship can be seen to have constitutive value, meaning that is an integral part of a greater valuable whole that does have intrinsic value, e.g. a flourishing human life or partnership [44*]. The greater valuable whole then is what 'has' or 'carries' the intrinsic value (its locus, as philosophers say [45]).

Thus in more practical terms, the intrinsic value of, say, a friendship, a love or a partnership is not in the relationships as such but in the whole triads of the two relata (friends, lovers, partners) and their relationships. The value of these relationships as such is constitutive value in these wholes. Figure 1 displays this in graphic form. Referring to people and nature, the relational triad includes humans, nature and their relationship in their dynamic interactions of encounter and response, in a myriad of instances running in scale from the interactions between a child and a dog, a farmer and her land, a community and its forest, a government agency designing a plan for landscape renewal, humanity struggling to keep the Earth whole.

Then, to what does the term 'relational value' refer? Specifying the broad definition of IPBES that relational values are 'values relative to the meaningfulness of relationships' (Stenseke, this volume), it appears we have a freedom for the term to mean either or both of (1) the intrinsic value of relational 
triads or (2) the constitutive value of the relationship per se. This gives rise to a need for clarity. We cannot say that relationships are ends in themselves, for instance, or think that a 'partnership landscape' consists only of good relationships (see next section).

All of us shape (constitute) relationships, and relationships shape (constitute) us. Because of this constant dynamic in relational triads, relational language is process language rather than 'things language'. For both Whitehead and Heidegger, the unified bodily/mental experience of the world rather than the objectifying gaze at the world is the most fundamental 'process element' of being in and becoming of the world [ $\left.41^{*}\right]$. This experience, as [41] puts it, is "value-soaked" from the very beginning. For this reason, Cheney and Weston [46] reject the traditional notion that ethics exist to sort the world ethically. Rather, we need to realize that ethics - our etiquette, as they say - precedes epistemology; our values, not our words, bring the world to presence.

Applying these general notions of relational value to nature specifically, we find that we cannot speak about the intrinsic relational value of nature; the locus of relational value is not in nature but in the whole triad of the relata (humans and nature) and their relationship. So, relational value with nature it shall be. Out of the value-soaked vague totality, relational values with nature - referring to both the intrinsic values of the humans-and-nature relational triad and the constitutive value of their relationship - emerge as the experienced goodness in experiences with nature. Following the original experience, relational values with nature can then crystallize in various forms, expressed for instance in flourishing human lives, exemplary partnerships or meaningful places. With respect to places, see [44*]. The next sections focus on the other two.

\section{Partnership with nature}

Partnership with nature is a term used in passing by various authors such as Korthals [47], Hourdequin and Wong [48] and even the queen of the Netherlands in her 1988 Christmas address [28]. The analytical basis of partnership with nature is found in Plumwood [49] and Cheney [5] who, without mentioning the term itself, created the conceptual space for something that goes beyond mastery over nature and stewardship but without reproducing some form of neo-Platonic or neo-Stoic unification (oneness) with nature. Two inhabitants of that space were Ebenreck [21] and De Groot [28] who, inspired by (female) farmers and (female) ethologists, respectively, set out to articulate the partnership ethic.

In De Groot's partnership ethic, the key principles for a good relationship are (i) the intensity of relationship, (ii) the harmony in the relationship and (iii) leaving space to each other. The first two of these clearly represent the quantitative and qualitative aspects of a good relationship, respectively. The third value is often forgotten by relationship enthusiasts who sometimes see relationships as ends in themselves [2], [50]. In the view propounded here, instead, intrinsic value resides in the triad of relationship and relata, and that value is more than just 'relationship density'. For a child, playing alone 
in the loving but non-interfering presence of the mother is of great constitutive value [5]. Likewise, there is goodness in a dolphin no one ever sees, i.e. pure wildness protected by our loving absence.

In a less systematic manner, other authors mention care, openness and vulnerability as key principles in the partnership ethic (e.g. Jax et al., this volume). Noteworthy as well is the agency-based and reciprocal tinge of the partnership idea. Terms like working together, give and take, bring into action, appropriate use, working relationship and so on are found in many places in partnership with nature literature, marking its potential for innovative conservation policies in areas of material interactions with nature such as farming and forestry.

Although a real analysis has yet to be carried out, the work of French anthropologist Descola [51] appears to offer an opportunity to embed the partnership idea in a wider set of cultural thought. Descola distinguishes four ways to be in the world and perceive that world ('ontologies'): naturalism, analogism, animism and totemism. The first two of these are characteristically Western. Naturalism depicts the world as inhabited by many different species sharing only one thing: substance. Analogism goes a step further and states that all beings differ in all aspects and are only ordered hierarchically, with humans on top. Animism holds that all beings, though differing in substance and organisation, share a deeper vital force. Totemism expresses that all beings share both substance and deeper vitality, and can share organisation. In Descola's scheme, therefore, totemism holds the possibility of a basic kinship between humans and other species, and the idea of partnership with nature may be seen as an affirmation of totemism in the West.

\section{Nature-inclusive eudaimonia}

As said, humans are born relata. That is why the ideas of relational value and eudaimonia (the good, meaningful, worthwhile life) are intimately bound; good relations are key constituents of the good life.

As Aristotle found already and as restated by O'Neill [52], the worthwhile life is distinct from a life of endless material consumption in pursuit of hedonic happiness. It follows that fostering eudaimonic rather than hedonic action in people, for instance through re-emphasizing relational values, is good for nature and the environment in general. Note that this holds irrespective of whether the relationship with nature is included in people's conception of the good life or not.

With the concept of 'nature-inclusive eudaimonia', we mean a flourishing life in which nature is an integral part (constitutive value). It is a life-with-nature, not necessarily a more radical life-for-nature as exemplified by the committed actors of the BIOMOT study. Nature-inclusive eudaimonia is potentially accessible to many, including people whose primary commitments lie elsewhere, e.g. in a social direction.

We can now address the question of what could be the 'special good' of nature-inclusive eudaimonia compared to eudaimonia in general. This special good is not self-explanatory. Of the 38 chapters in 
Vittersø's [53] eudaimonia bible, for instance, none discusses nature-inclusive eudaimonia. Then, why foster nature-inclusive eudaimonia specifically? The answer is not that nature would somehow be essential to a good life - as if a life devoted to, say, raising five children and volunteering for refugees could not be a worthwhile life [38].

Three reasons do appear to apply, however, to assume that a warm relationship with nature, though not essential, is good for all lives. (1) On a theoretical note, we may posit nature - wild nature especially - as our most fundamental Other, and therewith, following Aristotle's principle that the other teaches us who we are [54], as our deepest source of identity and context for meaning [55]. Many cross-cultural sources, from legends to legislation, support the idea that meaningful relations with nature are fundamental for flourishing lives [56]. (2) The experience of relationship with nature has capacities for growth, health and healing that no other relationship can provide, as shown in countless studies on short medical interventions [57] and long wilderness experience [58]. (3) Virtually all committed actors for nature in the already cited BIOMOT research shared lively stories of how encounters with nature coconstituted their lives. We believe this is no coincidence. Even people who may never become conservation activists change perspectives when nature is 'let in' [59]. At the end of a bush adventure therapy, the young drug addict "turned to [his therapist] with a huge grin and said: "You know what? I'm starting to like these $f^{* *}$ ing trees!'" [60]. We conclude that even though not essential, the inclusion of relational values with nature in people's lives is not only good for these lives but also good for conservation [61].

The final question then is how nature-inclusive eudaimonic desire and action may be encouraged and enabled in society. The policy recommendations of Chan et al. [2] already go a long way in this respect. Involving people in nature-inclusive activities helps internalize relationships and breed nature-inclusive eudaimonia - if only because attitudes often follow actions rather than the other way around [62]. Additionally, fostering positive childhood experiences with nature will be of great support [63], Brittos dos Santos and Gould (this volume). The BIOMOT project findings show that nature that can coconstitute lives in childhood can be found anywhere, from the urban brownfields to the beach and forest [64]. And what counts then is not so much the view but the intensity of (unsupervised) experience. This is important to urban planners [65] as well as to schools and parents: get them there, then leave them alone.

\section{Conclusion}

In this paper, we have seen that the language of relational values can be improved and we explored the concepts of partnership with nature and nature-inclusive eudaimonia as expressions of relational values. Maybe most importantly, we found that that relational values are real in the lives and ideas of people everywhere. In a way then, the current interest in relational values in Western philosophy is an act of catching up with reality. Having done so, philosophy may certainly help. Ideas of partnership and eudaimonia are there to critically strengthen; new practices in conservation are there to further ground and inspire; a myriad of empirical findings are there to retell and reinforce with deeper insights. And 
finally, the critical analysis of the nature-for-people ('ecosystem services') paradigm in conservation will remain a worthy cause for relational philosophy for some time to come.

\section{References}

1. Mace GM: Whose conservation? Science 2014, 345:1558-1560.

2. Chan KMA, Balvanera P, Benessaiah K, Chapman M, Díaz S, Gómez-Baggethun E, Gould R, Hannahs N, Jax K, Klain S, et al.: Why protect nature? Rethinking values and the environment. Proceedings of the National Academy of Sciences 2016, 113:1462-1465.

3. Morito B: Intrinsic Value: A Modern Albatross for the Ecological Approach. Environ Values 2003, 12:317-336.

4. Fox W: Toward Transpersonal Ecology. Boston: Shamahala; 1990.

5. ${ }^{*}$ Cheney J: The neo-Stoicism of radical environmentalism. Environ Ethics 1989, 11:293-325.

This paper relates deep ecology to Greek stoicism, in which the tragic loss of the classic polis was compensated by identification of the Self with the whole of the Cosmos, erecting a metaphysical tower beyond pain and suffering. This way, Cheney underpins an earlier (1987, same journal) account that argues, tortuously but fascinatingly, that the tragic separation of the masculine self from his mother/nature is compensated by the (physical) conquering of nature mixed with the (metaphysical) unification with the whole of Nature, as the two prongs of the same masculine project.

6. * Van den Born RJG, Arts B, Admiraal J, Beringer A, Knights P, Molinario E, Horvat KP, Porras-Gomez C, Smrekar A, Soethe N, et al.: The missing pillar: Eudemonic values in the justification of nature conservation. J Environ Planning Manage 2017:1-16.

Jointly with the more informal booklets [7] and [64], this paper presents the results of the BIOMOT project, especially its findings on nature-inclusive eudaimonia as the key driver of committed action for biodiversity. It emphasizes that the value of nature in fostering meaningful lives and communities, next to nature's instrumental value (ecosystem services) and intrinsic value, should become an ethical pillar under biodiversity policies, and may be key to closing the wide 'implementation gap' these policies still suffer from.

7. De Groot WT, Bonauito M, Dedeurwaerdere T, Knippenberg L: A theory of Committed Action for Nature: Key outcomes of the BIOMOT project. Edited by. Nijmegen: ISiS, Faculty of Science, Radboud University; 2015.

8. Admiraal JF, Van Den Born RJG, Beringer A, Bonaiuto F, Cicero L, Hiedanpää J, Knights P, Knippenberg LWJ, Molinario E, Musters CJM, et al.: Motivations for committed nature conservation action in Europe. Environ Conserv 2017, 44:148-157.

9. Flint CG, Kunze I, Muhar A, Yoshida Y, Penker M: Exploring empirical typologies of human-nature relationships and linkages to the ecosystem services concept. Landscape Urban Plann 2013, 120:208-217.

10. Mayer FS, Frantz CM: The connectedness to nature scale: A measure of individuals' feeling in community with nature. Journal of Environmental Psychology 2004, 24.

11. Nisbet EK, Zelenski JM, Murphy SA: The Nature Relatedness Scale: Linking Individuals' Connection With Nature to Environmental Concern and Behavior. Environment and Behavior 2008, 41:715740.

12. Gosling E, Williams KJH: Connectedness to nature, place attachment and conservation behaviour: Testing connectedness theory among farmers. Journal of Environmental Psychology 2010, 30:298-304. 
13. Vining J, Merrick MS, Price EA: The Distinction between Humans and Nature: Human Perceptions of Connectedness to Nature and Elements of the Natural and Unnatural. Hum Ecol Rev 2008, 15:1-11.

14. Martin C, Czellar S: The extended Inclusion of Nature in Self scale. Journal of Environmental Psychology 2016, 47:181-194.

15. Klain SC, Olmsted P, Chan KMA, Satterfield T: Relational values resonate broadly and differently than intrinsic or instrumental values, or the New Ecological Paradigm. PLOS ONE 2017, 12:e0183962.

16. * De Groot M, Drenthen M, De Groot WT: Public visions of the human/nature relationship and the implications for environmental ethics. Environ Ethics 2011, 33:25-44.

This paper, emphasizing philosophical underpinnings rather than social-scientific methodology, offers an accessible overview of the outcomes of the HaN scale studies in Europe that include the partnership with nature vision.

17. Verbrugge LNH, Van den Born RJG, Lenders HJR: Exploring Public Perception of Non-native Species from a Visions of Nature Perspective. Environ Manage 2013, 52:1562-1573.

18. Duong TB, Van den Born RJG: Thinking about Nature in the East: An empirical investigation of Visions of Nature in Vietnam. Forthcoming in Ecopsychology.

19. Arias-Arévalo P, Martín-López B, Gómez-Baggethun E: Exploring intrinsic, instrumental, and relational values for sustainable management of social-ecological systems. Ecol Soc 2017, 22:43.

20. Kahn P: The human relationship with nature: development and culture. Cambridge MA: The MIT Press; 1999.

21. Ebenreck S: A partnership farmland ethic. Journal of Environmental Ethics 1983, 5:33-45.

22. Causey AN: On the morality of hunting. Environ Ethics 1989, 11:327-343.

23. Dutcher DD, Finley JC, Luloff AE, Johnson JB: Connectivity With Nature as a Measure of Environmental Values. Environment and Behavior 2007, 39:474-493.

24. Lokhorst AM, Hoon C, le Rutte R, de Snoo G: There is an I in nature: The crucial role of the self in nature conservation. Land Use Policy 2014, 39:121-126.

25. Kaltenborn BP, Linnell JDC, Baggethun EG, Lindhjem H, Thomassen J, Chan KM: Ecosystem Services and Cultural Values as Building Blocks for 'The Good life'. A Case Study in the Community of Røst, Lofoten Islands, Norway. Ecol Econ 2017, 140:166-176.

26. Jackson S, Palmer LR: Reconceptualizing ecosystem services: Possibilities for cultivating and valuing the ethics and practices of care. Progress in Human Geography 2014, 39:122-145.

27. Christ CP: She Who Changes. New York: Palgrave MacMillan; 2003.

28. * De Groot WT: Environmental Science Theory: Concepts and Methods in a Problem-oriented, Oneworld paradigm. Amsterdam: Elsevier; 1992.

Though old and mildly over-enthousiastic, this work, on the web as

http://hdl.handle.net/1887/11548, represents the most expansive exploration of the partnership with nature idea, including its practical ethics and linkages to feminism and

Christian religion, its precursors and the alternative visions of mastery, stewardship and oneness with nature that later gave rise to the HaN scale [16].

29. Hardmeier C: Erzähldiskurs und Redepragmatik im Alten Testament: unterwegs zu einer performativen Theologie der Bibel. Tübingen: Mohr Siebeck; 2005.

30. Schillebeeckx E: Jezus, het verhaal van een levende. Bloemendaal: Nelissen; 1974.

31. Mommaers P: Hadewijch - Writer, Beguine, Love mystic. Leuven: Peeters; 2004.

32. Said AA, Funk NC: Peace in Islam: An ecology of the spirit. In Islam and Ecology: A bestowed trust.

Edited by Foltz RC, Denny FM, Baharudding A: Harvard University Press; 2003:155-183. 
33. Haq SN: Islam and Ecology: Toward retrieval and reconstruction. In Islam and Ecology: A bestowed trust. Edited by Foltz RC, Denny FM, Baharuddin A: Harvard University Press; 2003:121-154. Jointly with [32] in the same volume, this chapter is a learned but accessible introduction on the roots of the Islamic vision of nature and the human position in it, structured around three dimensions of the Qur'anic discourse: metaphysical, naturalistic and human. Topics discussed range from nature as the second Qur'an and the trust of stewardship down to the practical principles of conservation and animal care.

34. Wong DB: Identifying with nature in early Daoism. J Chin Phil 2009, 36:568-584.

35. Feng G-F, English J: Tao Te Ching: A new translation. London: Wildwood House; 1973.

36. Hassoun NJ, Wong DB: Conserving Nature; Preserving Identity. J Chin Phil 2015, 42:176-196.

37. Ingold T: The Perception of the Environment: Essays on livelihood, dwelling and skill. London: Routledge; 2000.

38. Baumeister RF, Leary MR: The need to belong: Desire for interpersonal attachments as a fundamental human motivation. PsyB 1995, 117:497-529.

39. Fiske ST: Social Beings; Core social motives and social psychology. Hoboken: John Wiley; 2009.

40. Wilson EO: Biophilia: The human bond with other species. Cambridge, MA: Harvard University Press; 1984.

41. Muraca B: Relational values: A Whiteheadian alternative for environmental philosophy and global environmental justice. Balkan Journal of Philosophy 2016, 8:19-38.

This paper offers a good introduction and interpretation of Whitehead's thought with respect to relational value. Whitehead is especially important because rather than viewing relational value as a sort of "number three value" (next to the intrinsic value of humans and nature separately) as most other authors do, Whitehead positions relational value as prior to all others, creating our world before separate identities and language emerge.

42. Muraca B: The Map of Moral Significance: A New Axiological Matrix for Environmental Ethics. Environ Values 2011, 20:375-396.

43. Lekan T: Friendship as an Impersonal Value. SW Phil Rev 2010, 26:71-79.

44. James SP: Ecosystem services and the value of places. Ethical Theory and Moral Practice 2016, 19:101-113.

Augmented by analytical clarity and brevity, this paper is important for two reasons. (1) It clarifies the position of relational value beyond the instrumental/intrinsic dichotomy, and (2) it focuses on meaningful places as expressions of relational value, thereby adding to our discussion on partnership and eudaimonia.

45. Lee K: The source and locus of intrinsic value: A re-examination. Environ Ethics 1996, 18:297-309.

46. Cheney J, Weston A: Environmental ethics as environmental etiquette: Toward and ethics-based epistemology. Environ Ethics 1999, 21:115-134.

47. Korthals M: Normatieve aspecten van de mileuproblematiek. Intermediair 1978, 14:41-47.

48. Hourdequin M, Wong DB: A relational approach to environmental Ethics. J Chin Phil 2005, 32:19-33.

49. Plumwood V: Feminism and the Mastery of Nature. London: Routledge; 1993.

50. Guha R: The paradox of global environmentalism. Current History 2000, 99:367-370.

51. Descola P: Beyond Nature and Culture. Chicago: University of Chicago Press; 2013.

52. O'Neill J: Happiness and the Good Life. Environ Values 2008, 17:125-144.

53. Vittersø J (Ed): Handbook of Eudaimonic Well-Being Berlin: Springer; 2016.

54. Freiman C: Goodwill Toward Nature. Environ Values 2009, 18:343-359.

55. Goodin R: Green Political Theory. Cambridge: Polity Press; 1992.

56. Nussbaum M: Creating Capabilities: The Human Development Approach. Cambridge, MA: Harvard University Press; 2011. 
57. Roe J, Aspinall P: The restorative benefits of walking in urban and rural settings in adults with good and poor mental health. Health Place 2011, 17:103-113.

58. Knapp CE, Smith TE (Ed): Exploring the Power of Solo, Silence, and Solitude Boulder: Association for Experiential Education; 2005.

59. Sarkar S: Biodiversity and Environmental Philosophy: An Introduction. Cambridge: Cambridge University Press; 2005.

60. Nicholls V, Gray T: Sense and sensibility: Reality and romanticism in human/nature relationships. Edited by; 2015:9.

61. Finger M: From Knowledge to Action? Exploring the Relationships Between Environmental Experiences, Learning, and Behavior. J Soc Iss 2010, 50:141-160.

62. Holland RW, Verplanken B, Van Knippenberg A: On the nature of attitude-behavior relations: the strong guide, the weak follow. European Journal of Social Psychology 2002, 32:869-876.

63. Wells NM, Lekies KS: Nature and the Life Course: Pathways from Childhood Nature Experiences to Adult Environmentalism. Children, Youth and Environments 2006, 16:1-24.

64. De Groot WT, Bonauito M, Dedeurwaerdere T, Knippenberg L: Fostering Committed Action for Nature: Policy and action recommendations from the BIOMOT project. Edited by. Nijmegen: ISiS, Faculty of Science, Radboud University; 2015.

65. Gebhard U: Kind und Natur: Die Bedeutung der Natur für die psychische Entwicklung. Berlin: Springer VS; 2013. 


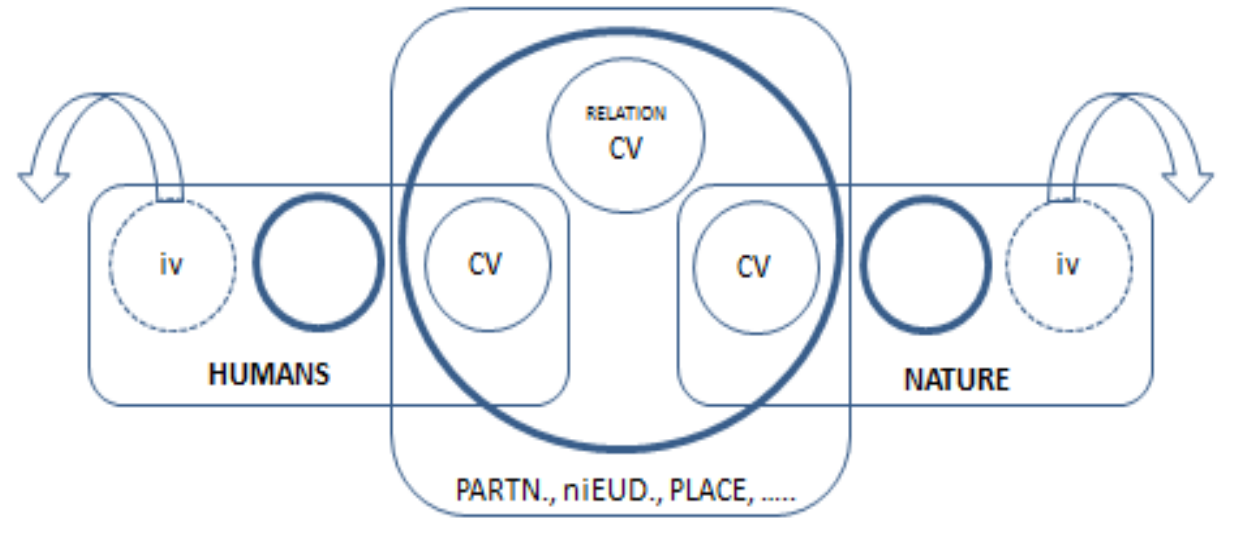

Figure 1: Instrumental, constitutive and intrinsic values of humans, nature and valuable relationship. The heavy circles indicate intrinsic value. $\mathrm{CV}=$ constitutive value; iv = instrumental value (of humans and nature for (other) humans and for (other) nature. Visible are the constitutive values of nature and people as relata as well as the constitutive value of the relationship, shaping the triads of partnership, nature-inclusive eudaimonia, meaningful places etc. that have intrinsic value. 
This research did not receive any specific grant from funding agencies in the public, commercial or not-for-profit sectors. 